Please share your stories about how Open Access to this article benefits you.

\title{
Encroachment by Word, Axis, and \\ Tree: Mapping Techniques from the \\ Colonization of New England
}

\author{
by Margaret W. Pearce
}

2013

This is the published version of the article, made available with the permission of the publisher. The original published version can be found at the link below.

Pearce, Margaret Wickens. (2004). Encroachment by Word, Axis, and Tree: Mapping Techniques from the Colonization of New England. Cartographic Perspectives (48):24-38.

Published version: http://www.dx.doi.org/10.14714/CP48.457

Terms of Use: http://www2.ku.edu/ scholar/docs/license.shtml 


\section{Encroachment by Word, Axis, and Tree: Mapping Techniques from the Colonization of New England}

\author{
Margaret W. Pearce \\ Department of Geography \\ Western Michigan Univ. \\ Kalamazoo, MI \\ 49008-5424 \\ margaret.pearce@wmich.edu
}

INTRODUCTION
It is well established that mapping has been an important tool for the colonization of North America. Techniques such as removal of toponymy, alteration of a boundary line location, and use of a map grid, were all successfully used for advancing colonial interests in the printed regional and national maps of the seventeenth and eighteenth centuries. This article compares these known techniques to those that were used in local, town level mapping in Connecticut during the same period. Whereas toponymic removal and replacement are found to remain central to cartographic encroachment at the local level, English colonists also successfully encroached on unpurchased Native lands through other uses of toponyms, as well as new devices such as the axis, tree-marking, and appropriation of Native mapping style. Native people actively contested these encroachments at the town and colony levels; these resistances successfully slowed but did not stop the mappings' effects. The final effectiveness of each encroachment technique is found to depend on its ability to maintain a vague definition of territory and boundaries within an aura of precision and legality.

$I^{\mathrm{t}}$ $\mathrm{t}$ is by now well known that the map has been a primary tool for colonizing North America. Since Brian Harley first asked us to consider the power of the map to coerce and control (Harley, 1988), the map's reputation as a mirror of nature has been supplanted by its reputation as a tool of colonizing culture. But how does one implement this colonizing effect, exactly? The power of the map may lie in the information it portrays or in the way that information is symbolized. If the power is in the symbol, which mark on the map encourages the imperial uses to which the maps are so successfully put?

For the printed promotional maps of the seventeenth and eighteenth centuries, we have some insight. Scholars have scrutinized the published cartography associated with, for example, Smith, Bellin, and Cook, for the colonial devices practiced and perfected in their printed geographies (Harley, 1988; Belyea, 1996; Spark, 1995). The body of work by Smith and the others comprised one facet of the colonial cartographic enterprise: the published, European face, designed to portray European encroachments with the authority and finality required for encouraging financial investments from map readers. Mapping, meanwhile, suffused other facets of the colonial bureaucracy. In colonial mapping at the very large scale, in the minute daily transactions and incremental encroachments between colonizer and colonized at the local level, maps were created for other purposes and other audiences. Do the maps of these other facets draw on techniques comparable to their printed, small-scale counterparts?

In this article, I address the question of encroachment techniques used by colonists in the mapping of New England town boundaries using Connecticut as an example. I will first look at what is already known about 
encroachment techniques in printed maps of colonization. Next, I will turn to my findings from Connecticut land records and compare them to the known colonial techniques, outlining the ways in which they are similar as well as describing several techniques unique to local mapping. I will then bring the techniques back into context through the story of Native reaction and resistance to cartographic encroachments in one town.

This study provides a contrast to the literature of maps and colonial power. An initial exploration of Native map influence in the land records of southern New England indicated the need for a more detailed and systematic examination of the way in which Indians and colonists mapped and re-mapped colonial town boundaries over time (Pearce, 1998b). This initial exploration was expanded in an effort to take a more processual ${ }^{1}$ approach, with a close reading of one body of town records over time (Pearce, 1998a), rather than focusing on unrelated documents. For this close reading, I chose the region of the second wave of English colonization in Western Connecticut, an area of ten towns settled between 16701719; today, this same region is divided into many smaller towns carved from the original settlements (Figure 1). By choosing this region, I was able to look at the land transaction process as it had settled into custom between Native and English people, at a time when Native people could exercise their legal rights at the town and colony levels.

Within this study area, I analyzed over 200 land records for the ways in which maps were constructed and used by Native people and English colonists during the steady marginalization of Native villages and the establishment and incorporation of colonial villages. As part of this analysis, I gave particular attention to identifying the specific mapping techniques used for encroachment. Ultimately, a cartographic encroachment must come down to a word, a line, a gesture. Where was it? Through close readings of the records, I found techniques borrowed from the printed maps, but I also found new approaches developed for local benefit.

\section{Encroachment Techniques from the Printed Maps}

Harley began the colonial re-reading in 1988 by pointing to two techniques used to create the "toponymic silence" of Early Modern cartography (Harley, 1988:66). One was the technique of omission, when the mapmaker simply declines to include the indigenous world and leaves instead the blank spaces of the map. In his reading of Smith's A Map of Virginia, Harley also pointed to the technique of toponymic replacement, the practice of removing native toponyms and replacing them with a European label. Since then, the removal and replacement of Native toponymy has been the object of several historical studies, including D'Abate's (1994) essay on naming practices in Norumbega, and Sparke's (1995) reading of Cook's General Chart of the Island of Newfoundland.

Belyea (1996) expanded our awareness of cartographic techniques in her reading of eighteenth century maps from the North American interior. In Belyea's analysis of Bellin's Carte de l'Amerique septentrionale, she called on us to rethink the function of the cartographic grid, demonstrating that apart from its projecting properties, the grid is an extremely useful device for maximizing encroachment on Native land.

Finally, in her study of colonial techniques in promotional maps of British North America, Roper also noted the removal of native toponyms, but as well discovered other colonizing techniques in use, including the alteration or movement of a boundary line to encroach on unclaimed territory, and the movement of the locations of parallels to strengthen boundary claims (Roper, 1998).

\author{
"Ultimately, a cartographic \\ encroachment must come down \\ to a word, a line, a gesture. \\ Where was it?"
}




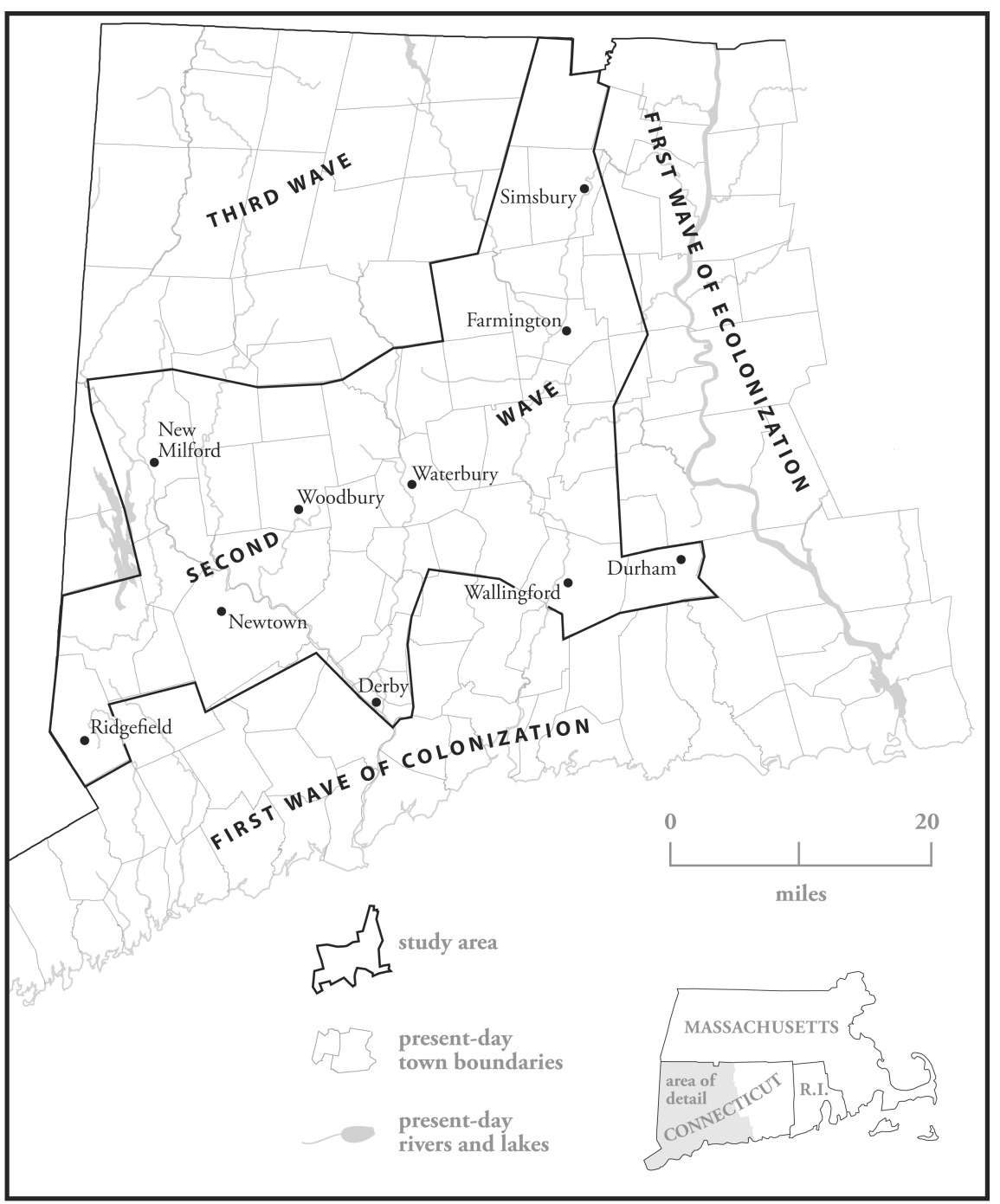

Figure 1. Context of the study area in present-day Connecticut.

"Latitude is less likely to be relevant to town mapping, where measure is scaled to smaller increments ..."
All of the aforementioned techniques, whether from the seventeenth or eighteenth centuries, were applied in mapping projects with a specific goal: colonial expansion and promotion through the dissemination of printed maps. The techniques, therefore, reflect the apparatus and theater of the printed map industry, an industry built on compiling the sketches of fur trappers and Indian interpreters into the notations of cartographers, enhancing the line quality of engravers, and supporting the production demands of publishing houses. For example, the cartographic technique of moving a boundary line to encompass more land is only useful if boundaries are graphically symbolized as lines. By the same terms, a line of latitude conveniently relocated for encroachment is only useful in a small-scale map of a large region, where degrees of latitude are appropriate measures of location or distance.

Latitude is less likely to be relevant to town mapping, where measure is scaled to smaller increments; in the seventeenth century, these increments would have been miles or rods and chains, with locational references to rivers, stones, and trees. Further, the very measurement of latitude, as well as the construction of a cartographic grid, depends on some degree of professional training on the part of the mapmaker. Such skills 
may not have been held by town proprietors founding colonial townships. In order, then, to gain a broader understanding of cartographic colonization techniques, it is necessary to include an examination of the colonizing techniques from local mapping processes, a facet of colonial mapping which operated at a different scale, with different tools and training, for a different audience.

\section{Mapping Town Boundaries in Southern New England}

There are no treaties in southern New England. The dispossession of the Native territory which would become Connecticut, Rhode Island, and Massachusetts, was achieved through the sale and purchase of Native land by groups of English town proprietors at selected sites within the colony's perimeter. It is, then, in the records of these land transactions, in particular the mapping of English town boundaries, that the taking of Native territory and re-mapping it as colonial territory initiated and evolved.

The process of mapping town boundaries in Connecticut, similar to that of other parts of southern New England, was an often lengthy process of negotiation, witnessing, and paperwork involving both Native and English people. When a new English town was to be settled, the town proprietors visited the land in question and made a verbal agreement with the Native people living at that location. Though the proprietors likely approached this agreement as the first step in land transfer, the agreement usually concerned not transfer of ownership but permission to utilize the land in a specific way, typically grazing or planting. The verbal agreement was followed by a more formalized "viewing" of the land by the proprietors, when they would make a visual survey of the land and write a report for the colony. At the same time deed negotiations began, when proprietors and Indians (with the assistance of interpreters, witnesses, and the town clerk) negotiated and recorded the terms and price of the land sale in a Native land conveyance. If the deed or conveyance was successful, a royal patent was issued for the land described in the deed. After receiving the patent, the proprietors held an official colonial declaration of the town bounds by witnessing and marking the corner trees or stones, a process in which Native people were often also involved. The final stage of mapping, formal survey of the land by a professional surveyor, often didn't occur until much later, sometimes as long as a century, following the declaration of the bounds.

With the exception of the final survey, the maps that resulted from this unique process were primarily composed of words, although graphic elements were incorporated in many instances. Verbal and written mapping, a combination of both Native and English mapping skills, was the prevalent mode for delineating property boundaries in southern New England up until the time of the Revolution (Pearce, 1998b).

This sequence, from verbal agreement to formal survey, describes town boundary mapping at its legal best. In practice, both the process and results varied widely from town to town, influenced by the local political and cultural conditions. When Native people were unwilling to sell, colonists adapted the sequence in a way which would best serve their needs. Patents were sometimes issued before a deed could be obtained, for instance, or proprietors negotiated with Native people having no rights to the land in question. On the other hand, because the mapping process necessitated Native approval or participation at specific intervals, Native people at times had the ability to influence the mapping process.
“. . because the mapping process necessitated Native approval or participation at specific intervals, Native people at times had the ability to influence the mapping process." 
"This technique of stretching the Native words from sites (places) to areas (spaces) was a highly successful means of encroaching on unpurchased lands."
In sum, the localized colonial mapping process in New England differed greatly from the colonial mapping in the small-scale, printed maps. These differences were not only based on the contrast in scale, but in the motivations and training of the people (Native or non-Native) who made and used the maps, the form of the maps which resulted, and the uses to which the maps were put. Local maps were intended only for town records and required legibility and legality sufficient to obtain the royal patent; they would never be published. The mapmakers, whether Native or non-Native, were not trained as surveyors, compilers, or engravers; instead, both cultures mapped by drawing on old traditions for property mapping handed down to them by their families (Bragdon, 1996; Cronon, 1983). Each had little regard for the graphic, and focused their attentions primarily on the ability of words to convey geographical information. Boundaries were expressed in a combination of Native and English terms, and the witnessing of the symbols of the boundaries on the ground (in trees and rocks) comprised an integral part of the map. From this process emerged a different palette of cartographic techniques for encroachment.

\section{Elements of Encroachment}

\section{Redefine the Words}

The most popular and effective technique for encroaching on un-purchased land was the colonial manipulation of the Native toponyms. In each of the land purchase negotiations, English proprietors found themselves purchasing land already mapped by Native people through toponym. These toponyms referred to specific places, a meadow or a river confluence, but not to a large region of land. It was these places for which Native people were negotiating in their land sales. The proprietors, on the other hand, wanted large tracts of five and ten square miles on which to build the colony's towns. To achieve the land transaction they wanted, proprietors first had to stretch and re-define the Native place name to suit their needs. This technique of stretching the Native words from sites (places) to areas (spaces) was a highly successful means of encroaching on unpurchased lands (Figure 2).

For example, Weantinock was the place name referring to a planting ground where the later-named Great Brook flowed into the Housatonic River. To the English, this became Weantinock, "a certain tract" comprising all of the land between the town of Danbury and the town of Woodbury (Wojciechowski, 1992:237). In this way, Weantinock became a word with two meanings, one in the Native world (the Weantinock that was a planting ground), and one in the non-Native world (the Weantinock that comprised a larger tract, within which was a planting ground).

This process not only changed the meaning and definition of Native place names, it also effectively erased entire Native toponymic landscapes by collapsing them into a single word, a word which had once referred to a single place within a web of places. The 1684 Native deed for Mattatuck, for example, described the land in negotiation as a region of twenty parcels, lying on both banks of the Naugatuck River (Figure 3) (Wojciechowski, 1992:131). The parcels were identified using 24 Paugussett toponyms. All but one of these toponyms, Mattatuck, were erased by the patent of 1686, and the word "Mattatuck" redefined in English terms to signify the entire space.

The other 23 toponyms, along with Mattatuck's original Native meaning, were removed from the land transaction but not forgotten. As became 


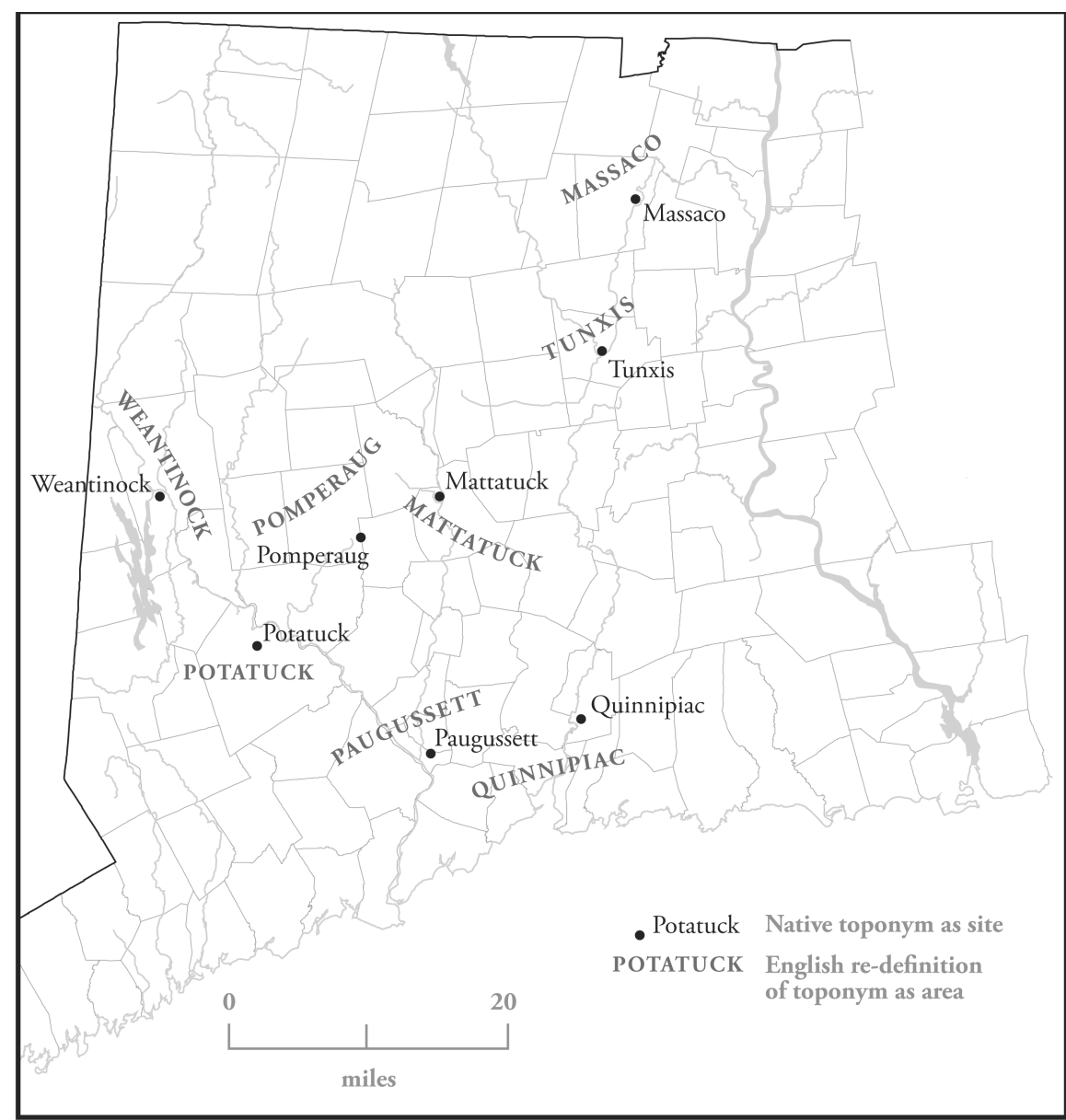

Figure 2. Sites become areas when Native toponymy is re-defined by English.

the norm throughout New England (indeed, throughout North America), the Native toponyms worked their way back into the landscape as colonial reinventions, redefined to stand for geographical features having clear boundaries. In Figure 3, for example, "Toantic Pond" lies in a place that in the Native world was mapped as Toantic. A similar toponymic reinvention brought Quassapaug Pond and the Naugatuck River onto the colonial map.

Once the Native place name was redefined and remapped in English terms, it could then be efficiently replaced with an English toponym, the colonizing technique commonly used in the colonial printed, regional maps. The royal patent which granted permission for proprietors to plant on their newly purchased lands bestowed authority by removing the English "Native" name and substituting an English name commemorative of the English landscape. So it was that Tunxis became Farmington, Massaco became Simsbury, Mattatuck became Waterbury, Paugussett became Derby, Pomperaug became Woodbury, Weantinock became New Milford, Coginchaug became Durham, and Quanneapague became Newtown. By the time that the territory was given its new English name, however, the original Native meaning and mapping, that which had been negotiated for sale, had long been erased by the proprietors.
"Once the Native place name was redefined and remapped in English terms, it could then be efficiently replaced with an English toponym ..." 
"The corners remained undefined and unbounded by a box, with infinite potential for stretching into additional regions of Native territory."

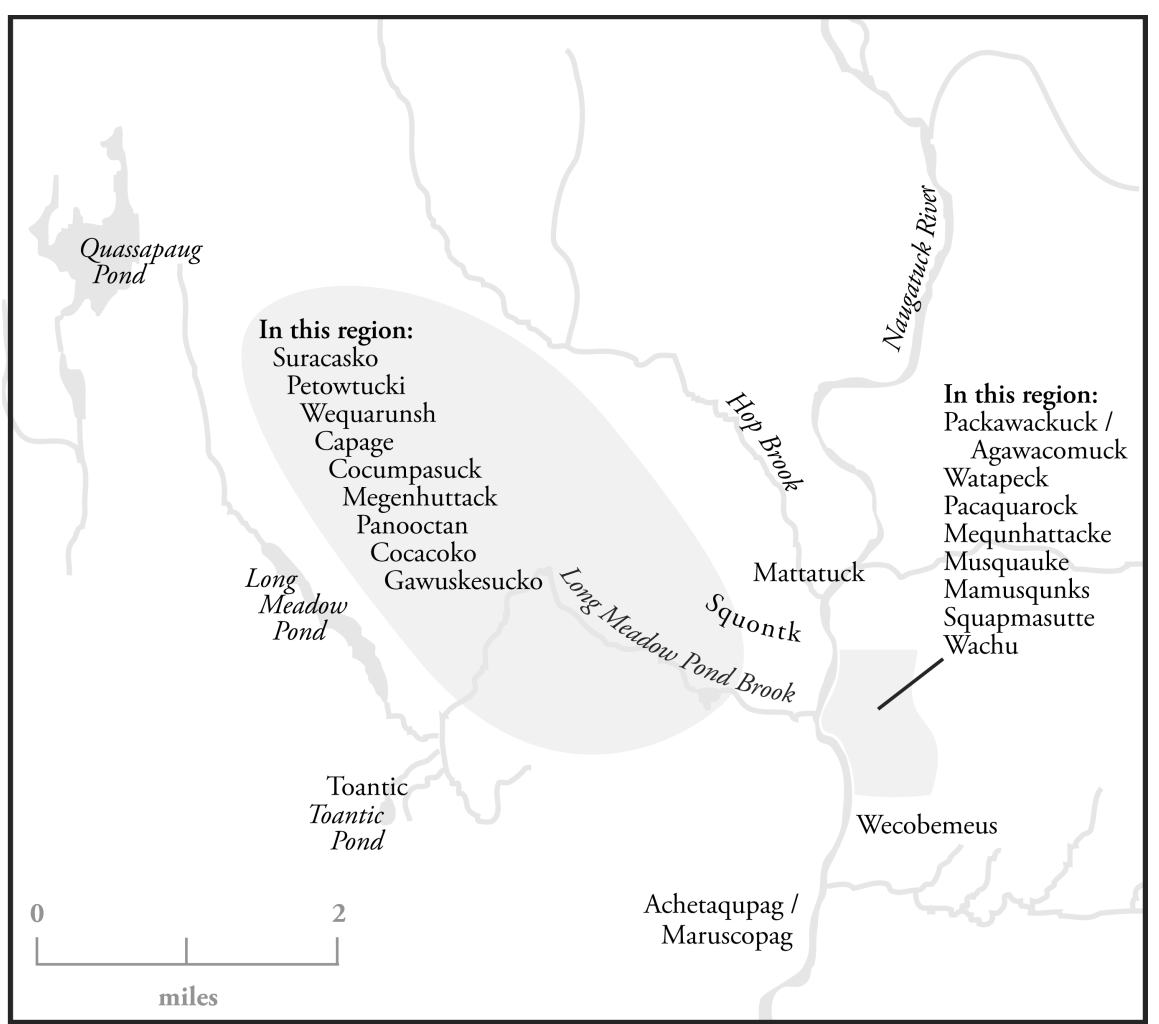

Figure 3. Native toponymy in 1684 before being re-mapped as "Mattatuck." Present-day toponymy appears in italics.

Use an Axis

While re-defining the Native place name from site to tract, in order to claim additional land, proprietors simultaneously defined the spaces of the tracts themselves in such a way as to maximize the size of their land purchases. The technique was to replace either the Native toponym or other description in the Native land transaction with an axis: two perpendicular lines of uncertain position and limitation on the landscape. This re-definition by axis was often used in the patent but sometimes it appeared in the Native land conveyance itself, in a separate section from the Native description of the territory. Unlike the grid's defined perimeters, a claim based on an axis had only the linear dimension of its axial lines. In the colonial land records, the axis typically intersected at the center of the town to be settled. The town proprietors, untrained in the surveying profession then on the rise back in England, had limited ability to measure and describe these lines as they moved away from the central point, thus ensuring the linear elasticity of the axial distances. The corners remained undefined and unbounded by a box, with infinite potential for stretching into additional regions of Native territory.

For example, the 1671 Native deed for territory which would become New Milford, defined a tract of land seven miles by six miles (Figure 4) (Wojciechowski, 1992:232). Simsbury was defined as ten miles north of the Farmington boundary and ten miles west of the Windsor boundary, although neither of these latter town boundaries had been run at that time (PRCC 2:127). In both New Milford and Simsbury, the vaguely defined corners of the axis, though useful mechanisms for encroaching on unpurchased lands, resulted in future Native land disputes in those corner spaces. 


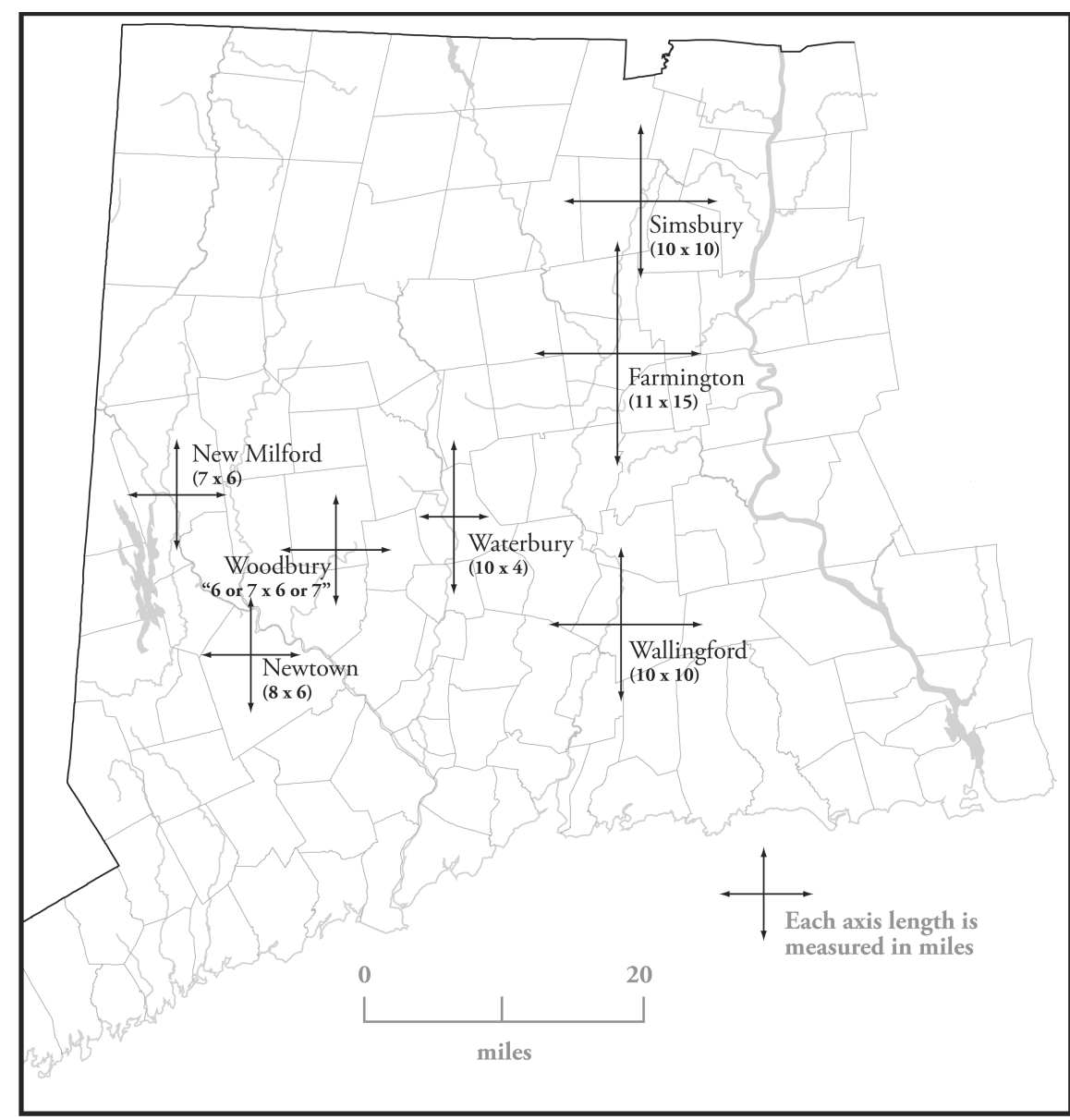

Figure 4. An axis gathers up land while leaving the perimeter undefined.

In the 1673 land sale at Woodbury, there was some initial attempt by the Potatucks to keep the axis distances under control. In the Potatuck conveyance, the territory was defined as an axis four miles by two miles, but with a defined perimeter of meadows, rivers, and existing home lots, as well as details about interior places included in the transaction (WTR, v. 2: 137). By the time of the 1683 patent, however, this specific axis with edges and details was redefined as an open-ended axis: seven miles by eight miles (Conn. Arch. TL, $1^{\text {st }}$ Series, VIII:152). The axial expansion of the patent beyond that of the Native deed resulted in disputes and retroactive purchases with the Potatucks until 1759 (WTR, v. 12:119).

\section{Mark Trees}

A third encroachment technique was to witness the corners by tree marking. Firm lines defining the edges of town boundaries were rarely a part of town boundary mapping in Western Connecticut until the final survey. Instead, edges were delineated by two or three marked trees or stones as the official "corners," the marking of which was an important part of the mapping process. Encroachment was achieved by marking trees outside the perimeter of the negotiated parcel.

For example, this technique was used by Wallingford colonists in New Haven Colony in 1660 to encroach on land held by the competing Connecticut Colony. Wallingford proprietors extended their boundaries further to the north onto territory claimed by Connecticut Colony by
"Encroachment was achieved by marking trees outside the perimeter of the negotiated parcel." 
"If a perimeter must actually be marked (whether on land or paper), one can still find opportunity for encroachment by placing the mark in a more expansive way." marking and witnessing of trees in that region. They further authenticated this encroachment by recording that the tree-marking was performed by Mantowese, a Quinnipiac person with whom the original Wallingford town boundaries had been negotiated (Conn. Arch. TL, $1^{\text {st }}$ Series, IV:66).

This technique is similar in spirit to that described by Roper of moving a boundary line on a map in order to take in more land (Roper, 1998). If a perimeter must actually be marked (whether on land or paper), one can still find opportunity for encroachment by placing the mark in a more expansive way. In the case of Wallingford, however, the strength of the encroachment hinged on Native involvement. Witnessing the corner was as much a Native mapping technique as it was English. Had the tree marking been performed by colonist alone, the claim would have been significantly weakened.

\section{Affect a Native Style}

In one case in the study area, proprietors used Native mapping style, or the appearance of such, as a device for authenticating a fraudulent claim to unpurchased lands. In a document filed in Woodbury in 1673, colonists drew a graphic map in a Native mapping style in order to give the appearance of having legitimately negotiated a land sale with the Indians for the site known as Pomperaug (Figure 5) (WTR v. 2:136).

This forged document was filed in the same year as Woodbury's controversial axial deed mentioned previously, a deed in which the Potatucks conveyed a tract of land disappointingly small to the proprietors. Frustrated by the unwillingness of the Potatuck people to relinquish Pomperaug to the Woodbury proprietors, an anonymous author fabricated a deed from words and pictures which recounted the sale of Pomperaug by Kenonge, Aromockomye, and Wecuppemee. To lend credibility to the forged document, the unknown mapmaker drew all line features as undifferentiated, solid, single lines, and all point features as undifferentiated, abstract, open circles, as was then typical of Native graphic style (Lewis, 1986). In Figure 5, the village of Potatuck on the Housatonic River, and the island on the Shepaug River, are depicted in the open-circle style; the Housatonic, Shepaug, and Pomperaug Rivers, and Eight Mile Brook, are depicted in the straight, geometric framework style. The success of this encroachment was temporary; a reading of the town records indicates that Potatuck people disputed the authenticity of this transaction at least by 1682 (PRCC v. 3:102; Wojciechowski 1992:207)

\section{Native Re-Mapping and Resistance at Tunxis}

Throughout the study area, the town proprietors' strategy of encroachment through various mapping techniques did not go unnoticed by Native people. Potatuck, Paugussett, Weantinock, Massaco, Mattatuck, and Tunxis people all actively disputed the encroachments at the town and colony levels, particularly in the late seventeenth century, using oral, written, and graphic mapping testimony to clarify the territorial descriptions in agreements and conveyances. Nowhere was this more powerfully illustrated than at Tunxis, the place that was eventually colonized as Farmington.

Tunxis Sepus, later abbreviated to Tunxis, was the site of a Native village and planting ground on what is today the Farmington River. In 1645, the colonial court granted permission to a group of proprietors to settle this place as Farmington. The town bounds were hazily described as a tract five miles by ten miles, with permission to "improve" an additional 


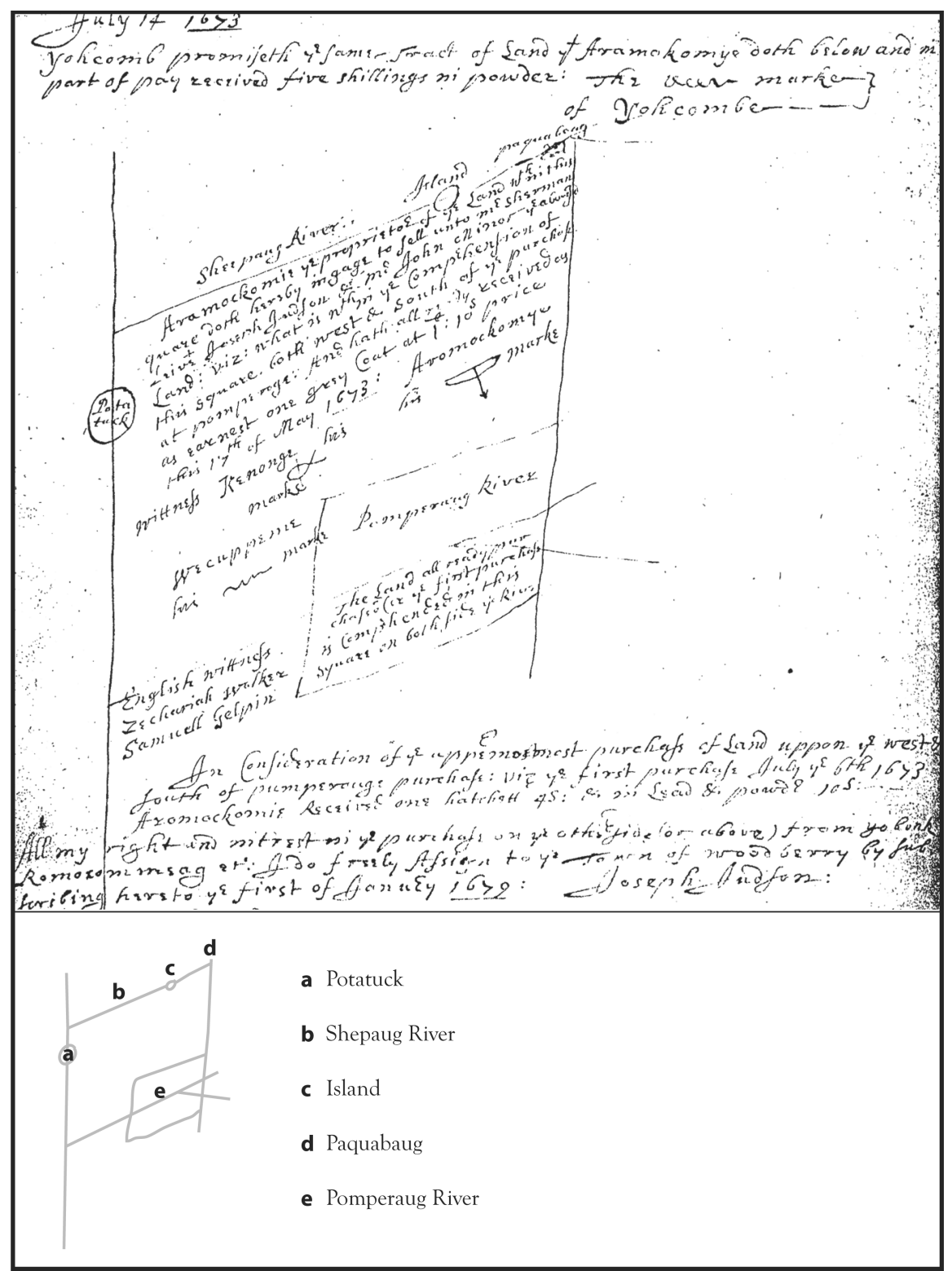

Figure 5. A fraudulent deed in Native style.

ten miles beyond the five (PRCC v. 1:133-34). The legal basis for this colonial settlement was a 1636 verbal purchase from an individual, the details of which were never recorded. From these dubious beginnings, colonists steadily began moving to Farmington from the Connecticut River Valley to compete for land with the Tunxis people.

By 1650, disputes between Tunxis and English land rights culminated in a deed to define which lands were reserved solely for Tunxis people. These territories were mapped as

Reserve ground in place together compassed about with a creke $\mathcal{E}$ trees, and now also too bee staked out... allso one Little slipe which Is allso to be staked out to prevent Contention (FLR, v. 1:2)

Despite the recording and staking of this Tunxis reserve, the bounds were not respected by colonists. On May 13, 1672, the Tunxis petitioned 
the General Court for return of their rightful territory, explaining that "wee shall have ground to believe that there is yett Justice to bee had from the english which is all wee desire" (CHS ms., 1672). In the petition was a graphic map, annotated by the court's clerk, explaining the delineation of territory in specific terms (Figure 6). As can be seen in the Figure, the Tunxis specifically bounded and described each parcel of land in its legal and political context.

A grievance committee was formed to resolve the Tunxis' claim, and the town records show the outcome of this committee in the form of a deed. Not to be out-mapped by the Tunxis, the English deed recorded three verbal mappings of the territory as well as a graphic map (Figure 7) (FLR, v. 1:43).

The difference in mapping between the initial petition in Figure 6, and the subsequent deed in Figure 7, is striking. In the deed, the town is once again mapped in terms of its theoretical axis, now extended to a full eleven by fifteen mile tract. A perimeter box is carefully included, but the

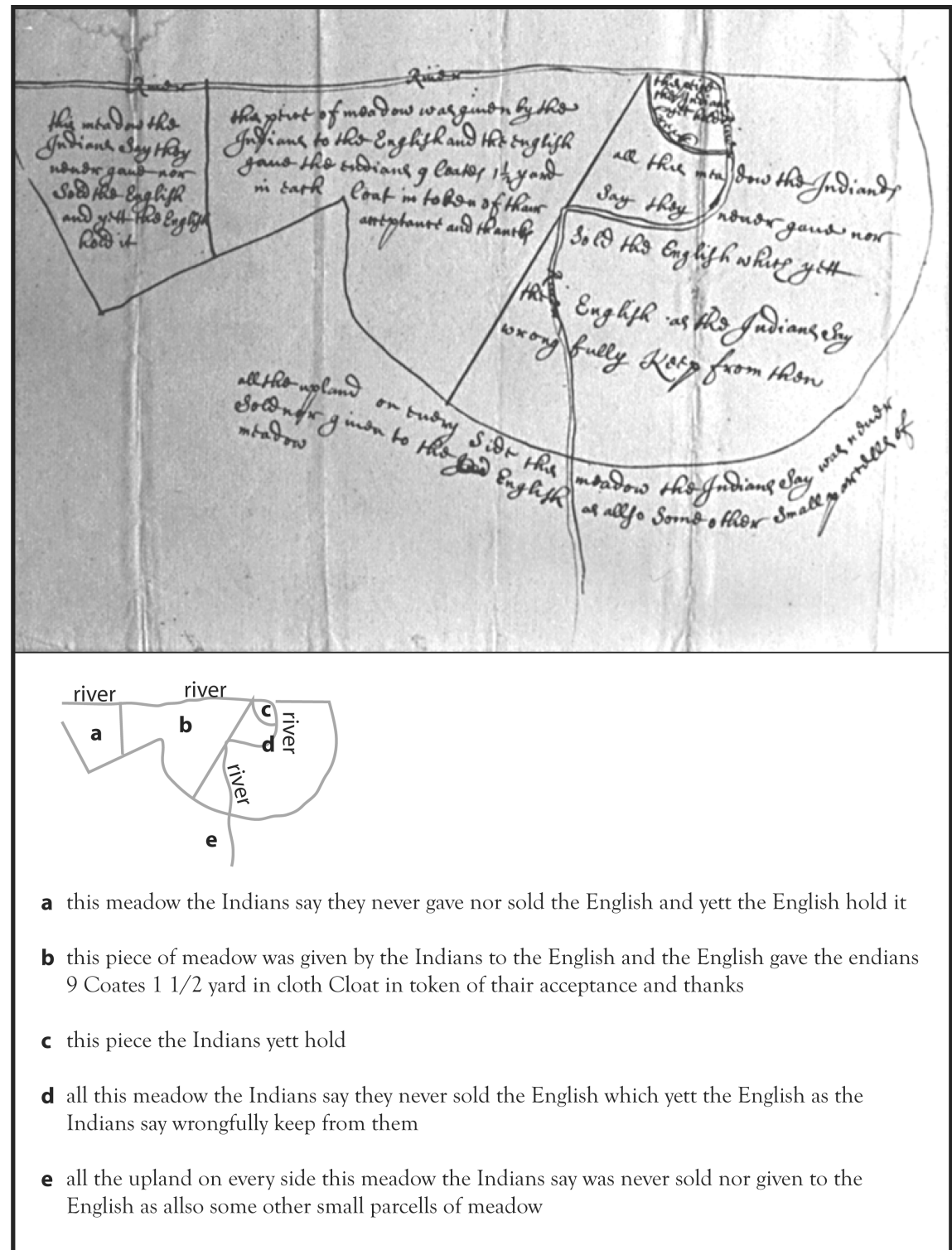

Figure 6. The Tunxis petition to the General Court. 


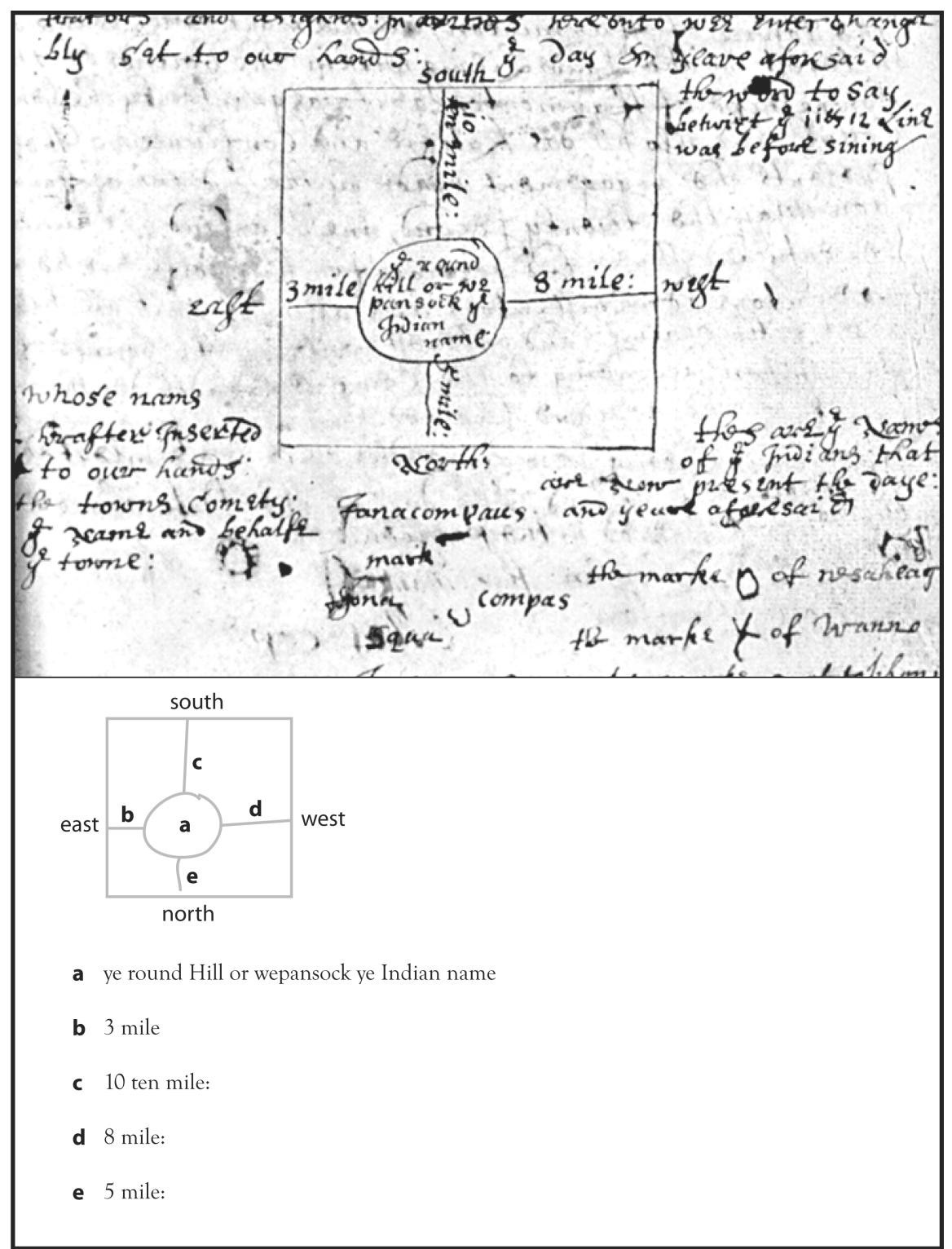

Figure 7. The deed in settlement of the Tunxis petition.

corners of the box are not described, and so remain efficiently disconnected from and undefined by the landscape. As was the convention, the axis is centered on a Native place, but the significance of this place to the Tunxis complaint is over-stated, if not fiction. Labeled "Ye round hill or wepansock ye Indian name," there was indeed a hill north of the river and near to the land parcels in dispute. But the hill was relevant to the English axis, not the Tunxis claim; the hill is neither described nor portrayed in the Tunxis petition, nor does the name "wepansock" appear in any other Farmington document, Native or non-Native.

In the deed's narrative, the committee acknowledges that the Tunxis retained rights to "two hundred acres of upland within ye Lands of their plantation...forthwith to be measured out to them." In a postscript, there is also mention of Tunxis rights to land at Indian Neck. But there is no description of the location of Indian Neck, nor of the previous two hundred acres. Where the Tunxis petition is precise regarding relative locations of parcels and their ownership histories, the colonial deed is vague or 
"The encroachments of the maps had effectively supported the encroachments on the ground, but because of Tunxis resistance and precise re-mapping, the process had taken a century." silent. And yet, the deed map appears to carry all information necessary for a legal land transaction, including a Native toponym, a graphic map in visual response to the Tunxis graphic, and verbal reference to Tunxis parcels.

The Tunxis claim to Indian Neck, the center of their territory and the coveted planting ground so desired by Farmington colonists, was repeatedly mapped in the town records with precision by Tunxis, and with ambiguity by English, in an ongoing struggle which continued for the next 100 years. In 1674, the Farmington proprietors voted to record Tunxis claims to the land at Indian Neck in the town records, but this record never transpired (FTMR v. 1: 273). In 1738, Tunxis men Jonathan Nopash and John Tanon appealed to the General Assembly to protect their rightful claim to Indian Neck, requesting that it not "be sacrificed to satisfy the avaricious humour of designing Englishmen" (Conn. Arch., IS I, 1:171). In 1767, the General Assembly heard another appeal for protection against encroachments at Indian Neck. In his testimony, James Wowowas summed up the settlement pressure at Indian Neck,

"which piece of ground the English people, Inhabitants of said town, have from time to time by little and little entered and encroached upon until they have gotten almost the whole thing" (Conn. Arch., IS I, 2:172).

By 1774, Tunxis people had lost the political power to remain on their land. The planting ground at Indian Neck was subdivided and sold as three lot sections, and the money funded the Tunxis removal to Oneida, New York (Conn. Arch. IS I, 2:193-94; CHS Ms 75832, Indian deeds 17741806; Bickford 1982:159-60). The encroachments of the maps had effectively supported the encroachments on the ground, but because of Tunxis resistance and precise re-mapping, the process had taken a century. On the eve of the Revolution, the Farmington colonists had finally, in Wowowas' words, "gotten...the whole thing."

\section{The Importance of Being Precisely Vague}

In summary, throughout the colonial period, English proprietors in western Connecticut utilized many mapping techniques in order to achieve their goal of obtaining as much unpurchased Native lands as possible. The most prevalent of these techniques, the removal and replacement of Native toponymy with English, was borrowed from the devices of colonial, printed cartography. But English colonists also developed other mapping strategies, twisting the meaning of the Native toponyms themselves, as well as making use of the axis, tree-marking, and even Native mapping style to claim lands not legally purchased.

In part, these differences from the techniques of the printed map industry were the direct result of scale. There was no use, for example, of lines of latitude in the town boundary descriptions, nor were there any instances of the use of the grid as a device for claiming control over adjacent areas. The differences may also have been the result of training because town proprietors possessed little if any formal training in land survey. Finally, the colonial techniques were developed to accommodate and manipulate the activities of Native people, with whom each land parcel was mapped and negotiated, and who retained a legal right to contest encroachments in the colonial courts until the eighteenth century.

Although the cartographic techniques ranged from written to graphic to marks on the landscape, they shared a common quality of stretching to include as much territory as possible while simultaneously remain- 
ing vague as to the limits of that territory, all within an aura of precision. Faced with Native peoples who were exacting both in their bounding of territory and in their protocol concerning rights to that territory, Connecticut colonists focused on techniques that would blur those precise bounds and avoid the certainty of the borders between land purchased and land reserved. The cumulative effect of the resulting locational ambiguities were so effective that, a century later when the towns were carved, felled, and grazed, and Native people pushed into poverty at the colonial margins, frustrated surveyors labored hopelessly to find exactly the boundary where one town ended and the next town began.

This article comes from a research project supported by fellowships at The Hermon Dunlap Smith Center for the History of Cartography at the Newberry Library, the John Carter Brown Library, and the American Association of University Women Educational Foundation, and by an Association of American Geographers Dissertation Grant. I would also like to thank G. Malcolm Lewis and an anonymous reviewer for comments.

\section{Primary Sources}

Conn. Arch.

Connecticut Archives, Connecticut State Library, Hartford.

IS Indian Series

TL Towns \& Lands

\section{CHS}

Connecticut Historical Society, Hartford.

\section{FLR}

Farmington Land Records, Connecticut State Library, Hartford.

\section{FTMR}

Farmington Town Meeting Records, Connecticut State Library, Hartford.

\section{PRCC}

Trumbull, J. Hammond, and Charles Hoadley, eds. 1850-90. The Public

Records of the Colony of Connecticut. 15 vols. Hartford.

\section{WTR}

Woodbury Town Records, Woodbury, Connecticut.

\section{Secondary Sources}

Belyea, B., 1996. Inland Journeys, Native Maps. Cartographica 33:2:1-16.

Bickford, C. P., 1982. Farmington in Connecticut. Canaan, N.H.: Published for the Farmington Historical Society by Phoenix Publishing.

Bragdon, K. J., 1996. Native People of Southern New England, 1500-1650. Norman: University of Oklahoma Press.

Bronson, H., 1858. The History of Waterbury, Connecticut. Waterbury: Bronson Brothers.
ACKNOWLEDGEMENTS

\author{
REFERENCES
}


Cronon, W., 1983. Changes in the Land: Indians, Colonists, and the Ecology of New England. N. Y.: Hill \& Wang.

D'Abate, R., 1994. On the Meaning of a Name: 'Norumbega' and the Representation of North America. In Baker, E. et al. (Eds) American Beginnings. Exploration, Culture, and Cartography in the Land of Norumbega, 61-88. Lincoln: University of Nebraska Press.

Daniels, B. C., 1979. The Connecticut Town: Growth and Development, 16351790. Middletown, Conn.: Wesleyan University Press.

Harley, J. B., 1988. Silences and secrecy: the Hidden Agenda of Cartography in Early Modern Europe. Imago Mundi 40:57-76.

Lewis, G. M., 1986. Indicators of Unacknowledged Assimilations from Amerindian Maps on Euro-American Maps of North America: Some General Principles Arising from a Study of La Verendrye's Composite Map, 1728-29. Imago Mundi, 38: 9-34.

Pearce, M. W., 1998a. Native and Colonial Mapping in Western Connecticut Land Records. PhD. thesis, Clark University.

Pearce, M. W., 1998b. Native Mapping in Southern New England Indian Deeds." In Lewis. G. M. (Ed), Cartographic Encounters: Perspectives on Native American Mapmaking and Map Use. Chicago: University of Chicago Press.

Rundstrom, R. A., 1991. Mapping, Postmodernism, Indigenous People and the Changing Direction of North American Cartography. Cartographica 28:2:1-12.

Roper, S. A., 1998. Paper Conquests: Early Modern English Mapping of North America as Promotional Tools. PhD. thesis, University of Kansas.

Sparke, M., 1995. Between Demythologizing and Deconstructing the Map: Shanawdithit's New-found-land and the Alienation of Canada. Cartographica 32:1:1-21.

Wojciechowski, F. L., 1992. Ethnohistory of the Paugussett Tribes: An Exercise in Research Methodology. Kiva Monograph Series No. 9. Amsterdam: De Kiva.

${ }^{1}$ The necessity of taking a processual approach to the interpretation of Native maps is described by Robert Rundstrom, in Rundstrom 1991. In this approach, maps cannot be studied as separate objects, isolated from the mapping processes which produced them. Rundstrom noted that this is especially true for indigenous cartography because it comes from incorporative, rather than inscriptive, cultural practices, and so cannot be disengaged from process. 